\title{
Influence of Vitamin B with or without Combined Use of Yakriton upon Glyoxalase Content in Human Milk.
}

\author{
rogth Report of the Peroxidase Reaction.
}

By

\section{Rokuro Orimo.}

(折茂六毁)

(From the Department of Pediatrics, Faculty of Medicine, Tohoku Imperial University, Sendai.

Director : Prof. A. Sato.)

The problem of glyoxalase was investigated by a number of authors. ${ }^{1-9)}$ It is especially interesting to note that $\mathrm{Find} \mathrm{la}^{6)}$ stated in his paper that the glyoxalase content of the liver in pigeons with beriberi is less than that in control pigeons, and that an administration of vitamin- $\mathrm{B}^{*}$ to a beriberic pigeon is followed by an increase in the glyoxalase content of the liver. In $1931 \mathrm{Vog} t-M \phi 1 l e \mathbf{r}^{10}$ found the decrease of liver enzyme in beriberic mice, and hypothesized that the symptoms of B-avitaminosis would be in a great part due to the intoxication of methyl glyoxal. N. A riya ma $\mathrm{a}^{11}$ reported in his paper that the glyoxalase content in the liver of beriberic pigeons in more decreased than that in normal pigeons. A. Takamats $\mathbf{u}^{12}$ in our Laboratory found the glyoxalase in human milk in only a small amount in the case

1) H. D. D a k in and H. W. D ud le y, J. of Biol. Chem., 1913, 14, 155,

2) H. D. D ak in and H. W. D ud l e $y$, J. of Biol. Chem., 1913, 14, 423.

3) H. D. Da kin and H. W. Dudley, J. of Biol. Chem., 1913, 15, 463.

4) C. Neuberg, Biochem. Z., 1913, 49, 502.

5) C. N euberg, Biochem. Z., 1913, 51, 484.

6) G. M. Find l ay, Biochem. J., 1921, 15, 104.

7) D. L. Foster, Biochem. J., 1925, 19, 757.

8) H. W. Dudley, Biochem. J., 1926, 20, 314.

9) N. A ri y a ma, J. of Biol. Chem., 1928, 77, 359.

* $B_{1}$ is meant throughout the paper by $B$, unless otherwise noted.

10) P. Vog t-M $\phi 11$ er, Biochem. Z., 1931, 233, 248.

11) N. Ariy a ma, Nippon Seikagakkai Kaiho, 1932, 7, 168.

12) A. T a ka matsu, Tohoku J. Exp. Med., 1938, 34, 509. 
of Arakawa-negative, and found that the glyoxalase in it will increase on an administration of vitamin $B$. In a preceding paper ${ }^{13)} I$ was able to confirm his result in a much larger number of materials. Human milk positive to Arakawa's reaction contains much glyoxalase, and that Arakawa-negative milk contains only a small amount of it. Ta$\mathbf{k}$ a $\mathbf{m}$ ats $\mathbf{u}^{\mathbf{1 2})}$ showed, though in only a few cases, that an administration of vitamin $B$ to Arakawa-negative mothers will result in an increase of glyoxalase in their milk. In the present paper I desire to report on my result of the influence of vitamin $B$ in a larger number of materials. Besides, I tried also the combined effect of vitamin $B$ and yakriton, because the latter would mobilize or fortify the effect of the former.

\section{Method of Experiment.}

The materials: Milk samples were obtained from "healthy" mothers during the stay of their breast-fed patients in our University Hospital. Milk was examined with Arakawa's reagent in each case. Of course the "healthy" mothers negative to Arakawa's reaction* were made objects of investigation in the present experiment, because human milk negative to Arakawa's reaction contains only a small amount of glyoxalase, and I wanted to increase it through an administration of vitamin B etc. As to the glyoxalase in human milk, it was determined according to the method of Dudley. ${ }^{14}$ ) As to the details I shall refer to the preceding paper. ${ }^{13)}$

All the cases reported in the present work were the result of a clinical experiment. They were all divided into 4 groups : Group of cases treated with vitamin B, Group of cases treated with vitamin B and yakriton, Group of cases treated with yakriton alone, and Group of cases with no treatment.

13) R. Orim o, Tohoku J. Exp. Med., 1939, 35, 34.

* Arakawa-positive may be used in two different senses. One of these is: Arakawa-positive in a biochemical sense. A sample of human milk is said to have become Arakawa-positive, when it becomes blue on the addition of A $\mathrm{rak}$ a wa's reagent. Here it means that the sample is not negative to A rakawa's reaction. The other of these two senses is: Arakawa-positive in a clinical sense. A sample of human milk is clinically Arakawa-positive only when it shows such a reaction as H or $\#$ in one minute of the addition of Arakawa's reagent. Another sample of human milk may be Arakawa-positive in the first described sense, but yet clinically negative.

14) H. W. Dudle s, Biochem, J., 1915, 9, 255. 


\section{Result of Experiment.}

Before relating of the result, it is to be noted here that the effect of the treatment may well be seen in such cases alone with a rather larger glyoxalase content after the treatment, as Nos. 1, 6, 8 and 10 in Table 1 , Nos. 2 and 3 in Table 2 and No. 1 in Table 3. As to such cases as No. 5 in Table 1, Nos. 4 and 8 in Table 2 and No. 2 in Table 3, for instance, it is difficult to relate definitely; in such cases we may be able to see only an inclination at most.

Group I. Cases treated with vitamin B alone (Cf. Table 1).

In the cases No. 1, 6 and 10, an increase of the glyoxalase content will be very evident. In most of the other cases an increase or at least an inclination of increase will be seen. There is no case in which glyoxalase decreased on an administration of vitamin $B$. It will be seen that an administration of the vitamin will act to increase the content of glyoxalase in human milk. However, the treatment ought to have been continued longer in Nos. 4 and 5 to effect a large glyoxalase content in their milk; especially a more energetic treatment might have been necessary for the beriberi mother in No. 4 .

Group II or the Group of cases treated with vitamin B and yakriton (Cf. Table 2).

In 5 of all the 8 cases the increase of glyoxalase was evident. In the other 3 cases only an inclination of the increase was seen, but there is no case in which a decrease of the enzyme occurred. In Nos. 4, 6 and 8 we ought to have treated them more energetically; in these cases the amount of the vitamin which the mothers claimed they had been taking was quite unknown.

Group III or the Group of cases treated with yakriton alone (Cf. Table 3).

There were only 3 cases belonging to the group and they showed an increase or an inclination of increase of glyoxalase. Why the group was so small in number of cases will be explained in the 'Comment'.

Group IV or the group of cases not subjected to any treatment (Cf. Table 4).

There were only 2 cases in this group and no increase of glyoxalase was seen in either case. Why the cases belonging to the group were scarce in number, will be explained in the 'Comment'. 
TABLE 1.

Increase of glyoxalase in Group $I$.

Group of cases treated with vitamin $B$.

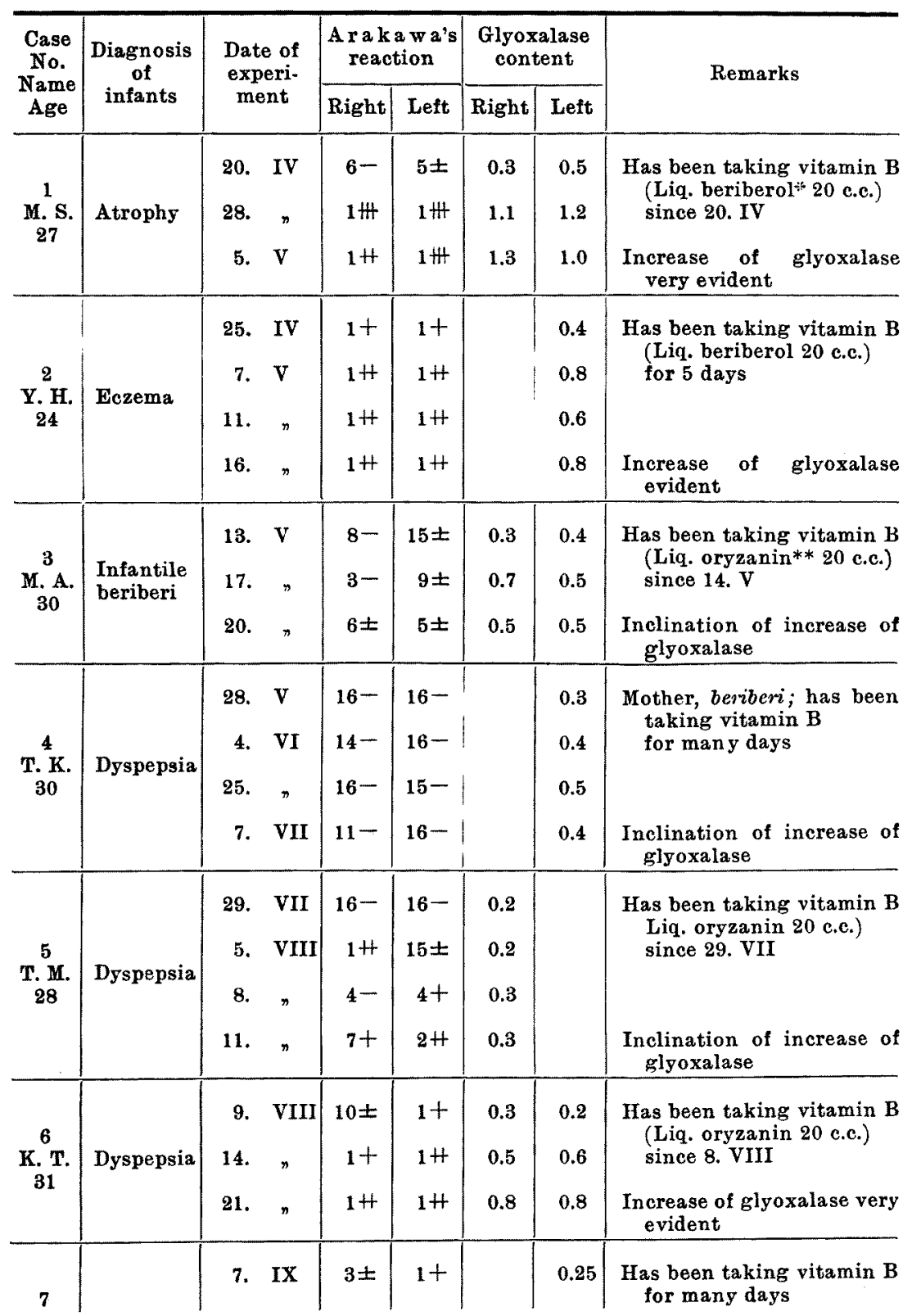




\begin{tabular}{|c|c|c|c|c|c|c|c|}
\hline \multirow{2}{*}{$\begin{array}{c}\text { Case } \\
\text { No. } \\
\text { Name } \\
\text { Age }\end{array}$} & \multirow{2}{*}{$\begin{array}{c}\text { Diagnosis } \\
\text { of } \\
\text { infants }\end{array}$} & \multirow{2}{*}{$\begin{array}{c}\text { Date of } \\
\text { experi- } \\
\text { ment }\end{array}$} & \multicolumn{2}{|c|}{$\begin{array}{l}\text { Arakawa's } \\
\text { reaction }\end{array}$} & \multicolumn{2}{|c|}{$\begin{array}{l}\text { Glyoxalase } \\
\text { content }\end{array}$} & \multirow{2}{*}{ Remarks } \\
\hline & & & Right & Left & Right & Left & \\
\hline $\begin{array}{c}\text { K. T. } \\
32\end{array}$ & Dyspepsia & $\begin{array}{l}\text { 26. IX } \\
\text { 2. X }\end{array}$ & $\begin{array}{l}3 \pm \\
4+\end{array}$ & $\begin{array}{l}1 H \\
1 H\end{array}$ & & $\begin{array}{l}0.4 \\
0.4\end{array}$ & $\begin{array}{l}\text { Inclination of increase of } \\
\text { glyoxalase }\end{array}$ \\
\hline $\begin{array}{c}8 \\
\text { Y. T. } \\
21\end{array}$ & Atrophy & $\begin{array}{l}\text { 13. } \mathrm{X} \\
15 . \\
19 . \quad \text { " } \\
22 . \quad \text { n }\end{array}$ & $\begin{array}{l}15- \\
16- \\
5 \pm \\
11 \pm\end{array}$ & $\begin{array}{l}16- \\
4- \\
16- \\
15-\end{array}$ & $\begin{array}{l}0.25 \\
0.2 \\
0.5 \\
0.8\end{array}$ & $\begin{array}{l}0.2 \\
0.2 \\
0.4 \\
0.7\end{array}$ & $\begin{array}{l}\text { Oryzanin fortior } * * * \text { (1.0 } \\
\text { c.c.) injected every day } \\
\text { since } 13 . \mathrm{X} \\
\text { Increase of glyoxalase very } \\
\text { evident }\end{array}$ \\
\hline $\begin{array}{c}9 \\
\text { K. S. } \\
28\end{array}$ & $\begin{array}{l}\text { Bron- } \\
\text { chitis }\end{array}$ & $\begin{array}{l}\text { 7. XI } \\
\text { 9. } \\
\text { 12. " }\end{array}$ & $\begin{array}{l}13- \\
12- \\
16-\end{array}$ & $\begin{array}{l}14- \\
16- \\
16-\end{array}$ & $\begin{array}{l}0.5 \\
0.7 \\
0.8\end{array}$ & & $\begin{array}{l}\text { Has been taking vitamin B } \\
\text { (Liq. beriberol } 20 \text { c.c.) } \\
\text { since } 7 . \text { XI } \\
\text { Inclination of increase of } \\
\text { glyoxalase }\end{array}$ \\
\hline $\begin{array}{l}10 \\
\text { E. K. } \\
27\end{array}$ & Atrophy & $\begin{array}{ll}14 . & 1 \\
18 . & n \\
23 . & n \\
25 . & n \\
28 . & n\end{array}$ & $\begin{array}{l}15- \\
16- \\
12- \\
12- \\
10 \pm\end{array}$ & $\begin{array}{r}10 \pm \\
10- \\
10 \pm \\
9 \pm \\
10 \pm\end{array}$ & \begin{tabular}{l|}
0.4 \\
0.35 \\
0.6 \\
1.2 \\
0.8
\end{tabular} & $\begin{array}{l}0.3 \\
0.4 \\
0.8 \\
1.0 \\
1.0\end{array}$ & $\begin{array}{l}\text { Oryzanin fortior ( } 1.0 \text { c.c.) } \\
\text { injected every day }\end{array}$ \\
\hline $\begin{array}{c}11 \\
\mathrm{~K} . \mathrm{U} \\
30\end{array}$ & Atrophy & $\begin{array}{r}\text { 4. II } \\
9 . " \\
\text { 13. } "\end{array}$ & $\begin{array}{l}16- \\
16- \\
16-\end{array}$ & $\begin{array}{l}16- \\
16- \\
16-\end{array}$ & $\begin{array}{l}0.1 \\
0.4 \\
0.3\end{array}$ & $\begin{array}{l}0.2 \\
0.4 \\
0.3\end{array}$ & $\begin{array}{l}\text { Oryzanin fortior ( } 1.0 \text { c.c.) } \\
\text { injected every other day } \\
\text { Increase of glyoxalase }\end{array}$ \\
\hline $\begin{array}{c}12 \\
\mathrm{~K} . \mathrm{K} \\
27\end{array}$ & $\begin{array}{l}\text { Pyloro- } \\
\text { spasm? }\end{array}$ & $\begin{array}{l}\text { 14. III } \\
17 . \quad \\
20 .\end{array}$ & $\begin{array}{l}3- \\
15- \\
16-\end{array}$ & $\begin{array}{c}3- \\
16- \\
12-\end{array}$ & $\begin{array}{l}0.1 \\
0.2 \\
0.3\end{array}$ & $\begin{array}{l}0.07 \\
0.1 \\
0.2\end{array}$ & $\begin{array}{l}\text { Has been taking vitamin B } \\
\text { (Liq. oryzanin } 20 \text { c.c.) } \\
\text { since 14. III } \\
\begin{array}{c}\text { Increase of glyoxalase } \\
\text { evident }\end{array}\end{array}$ \\
\hline $\begin{array}{c}13 \\
\text { R. } 0 . \\
34\end{array}$ & $\begin{array}{c}\text { Grippal } \\
\text { infection }\end{array}$ & $\begin{array}{l}\text { 30. III } \\
\text { 3. IV } \\
\text { 5. }\end{array}$ & $\begin{array}{l}4- \\
6- \\
2-\end{array}$ & $\begin{array}{l}16- \\
16- \\
16-\end{array}$ & $\begin{array}{l}0.2 \\
0.2 \\
0.4\end{array}$ & $\begin{array}{l}0.4 \\
0.4 \\
0.5\end{array}$ & $\begin{array}{l}\text { Has been taking vitamin } B \\
\quad \text { (Liq. oryzanin } 20 \text { c.c.) } \\
\text { for } 3 \text { days } \\
\text { Inclination of increase of } \\
\text { glyoxalase }\end{array}$ \\
\hline
\end{tabular}

* "Beriberol" is a vitamin B preparation of S. Tsukie containing vitamin B and diastase.

"Oryzanin" is a vitamin B preparation of U. Suzuki containing vitamin $\mathrm{B}_{1}$ and $B_{2}$. **** “Oryzanin fortior" $\left(1.0\right.$ c.c.) contains $0.5 \mathrm{mg}$. of vitamin $B_{1}$ crystal. 
Table of signs for showing different Arakawa's reaction.

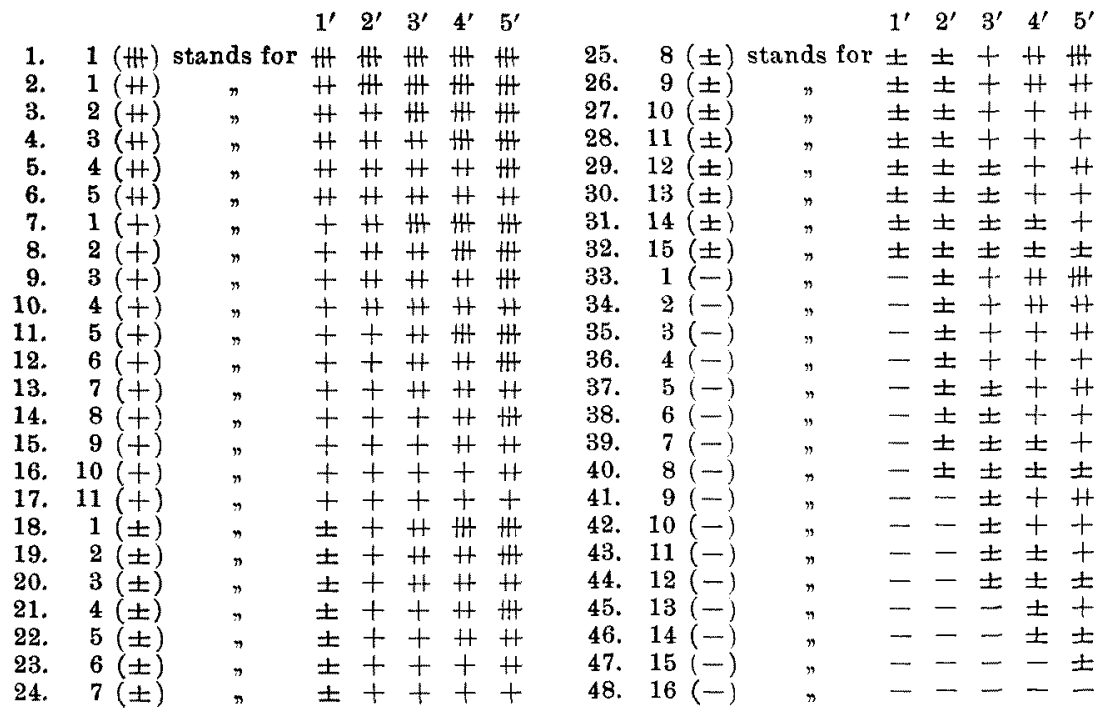

Explanation to the table:-

Take, for instance, the sign: $2(H)$. This stands for A rakawa's reaction with the course $(H) 1^{\prime}(H) 2^{\prime}(\#) 3^{\prime}(\#) 4^{\prime}(\#) 5^{\prime}$. The sign does not express any prompt result of the reaction, so the prompt reaction of the sign : $2(H)$ may be $(-) 0^{\prime},( \pm) 0^{\prime},(+) 0^{\prime}$ or even $(H) 0^{\prime}$, but this will not matter much, as the result of the reaction in one minute is the most important.

TABLE 2.

Increase of glyoxalase in Group II.

Group of cases treated with vitamin $B$ and yakriton.

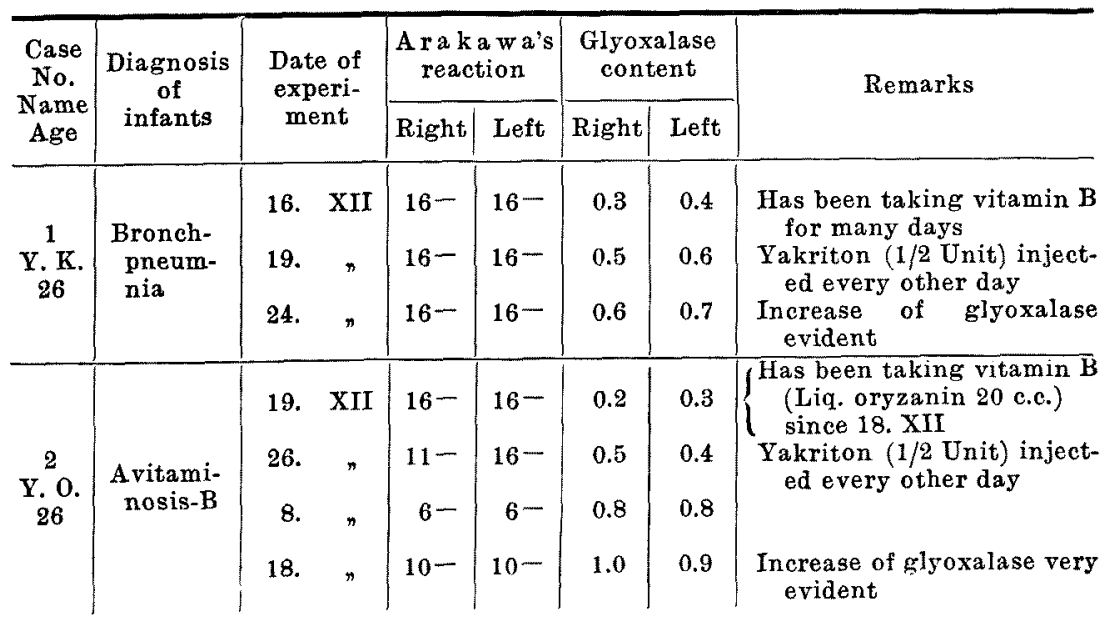




\begin{tabular}{|c|c|c|c|c|c|c|c|}
\hline \multirow{2}{*}{$\begin{array}{c}\text { Case } \\
\text { No. } \\
\text { Name } \\
\text { Age }\end{array}$} & \multirow{2}{*}{$\begin{array}{c}\text { Diagnosis } \\
\text { of } \\
\text { infants }\end{array}$} & \multirow{2}{*}{$\begin{array}{c}\text { Date of } \\
\text { experi- } \\
\text { ment }\end{array}$} & \multicolumn{2}{|c|}{$\begin{array}{l}\text { Arakawa's } \\
\text { reaction }\end{array}$} & \multicolumn{2}{|c|}{$\begin{array}{c}\text { Glyoxalase } \\
\text { content }\end{array}$} & \multirow{2}{*}{ Remarks } \\
\hline & & & Right & Left & Right & Left & \\
\hline $\begin{array}{c}3 \\
\text { H. I. } \\
25\end{array}$ & Dyspepsia & $\begin{array}{l}\text { 16. I } \\
21 . \quad \text { " } \\
24 . \text { " } \\
\text { 31. }\end{array}$ & $\begin{array}{l}16- \\
16- \\
16- \\
16-\end{array}$ & $\begin{array}{l}16- \\
16- \\
16- \\
16-\end{array}$ & $\begin{array}{l}0.7 \\
0.6 \\
1.0 \\
1.0\end{array}$ & $\begin{array}{l}0.8 \\
0.4 \\
0.6 \\
1.0\end{array}$ & $\begin{array}{l}\text { Has been taking vitamin B } \\
\text { (Liq. oryzanin } 20 \text { c.c.) } \\
\text { for } 4 \text { days } \\
\text { Yakriton (1/2 Unit) inject- } \\
\text { ed every other day } \\
\text { Increase of glyoxalase } \\
\text { evident }\end{array}$ \\
\hline$\underset{30}{\mathrm{H} . \mathrm{S}}$ & $\begin{array}{l}\text { Bron- } \\
\text { chitis }\end{array}$ & $\begin{array}{l}\text { 19. I } \\
22 . \\
26 . \quad n\end{array}$ & $\begin{array}{l}16- \\
16- \\
16-\end{array}$ & $\begin{array}{l}16- \\
16- \\
16-\end{array}$ & $\begin{array}{l}0.2 \\
0.3 \\
0.3\end{array}$ & $\begin{array}{l}0.2 \\
0.2 \\
0.2\end{array}$ & $\begin{array}{l}\text { Has been taking vitamin B } \\
\text { for } 3 \text { days } \\
\text { Yakriton ( } 1 / 2 \text { Unit) inject- } \\
\text { ed every other day } \\
\text { Slight inclination of in- } \\
\text { crease of glyoxalase }\end{array}$ \\
\hline $\begin{array}{c}5 \\
\text { T. C. } \\
25\end{array}$ & $\begin{array}{l}\text { B-avita- } \\
\text { minotic } \\
\text { dyspep- } \\
\text { sia }\end{array}$ & $\begin{array}{r}\text { 30. I } \\
\text { 3. II } \\
8 . \\
\text { 13. } \\
\text { 18. }\end{array}$ & $\begin{array}{c}8- \\
12- \\
16- \\
11- \\
3-\end{array}$ & $\begin{array}{l}15- \\
16- \\
16- \\
16- \\
14-\end{array}$ & $\begin{array}{l}0.1 \\
0.3 \\
0.5 \\
0.4 \\
0.5\end{array}$ & $\begin{array}{l}0.3 \\
0.4 \\
0.5\end{array}$ & $\begin{array}{l}\text { Has been taking vitamin B } \\
\text { (Liq. oryzanin } 20 \text { c.c.) } \\
\text { since } 31 \text {. I } \\
\text { Yakriton (1/2 Unit) inject- } \\
\text { ed every other day } \\
\text { Inerease of glyoxalase } \\
\text { evident }\end{array}$ \\
\hline $\begin{array}{c}6 \\
\text { T. S. } \\
30\end{array}$ & Dyspepsia & $\begin{array}{r}\text { 1. II } \\
6 . \quad 7 \\
10 . \quad "\end{array}$ & $\begin{array}{l}16- \\
13- \\
10 \pm\end{array}$ & $\begin{array}{l}16- \\
10- \\
9 \pm\end{array}$ & $\begin{array}{l}0.2 \\
0.3 \\
0.3\end{array}$ & $\begin{array}{l}0.2 \\
0.4 \\
0.3\end{array}$ & $\begin{array}{l}\text { Has been taking vitamin B } \\
\text { for many days } \\
\text { Yakriton ( } 1 / 2 \text { Unit) inject- } \\
\text { ed every other day } \\
\text { Inclination of increase of } \\
\text { glyoxalase }\end{array}$ \\
\hline $\begin{array}{c}{ }^{7} \\
\text { S. } 0 . \\
31\end{array}$ & Dyspepsia & $\begin{array}{l}\text { 2. III } \\
4 . \quad \\
8 . " \\
12 . \quad \%\end{array}$ & $\begin{array}{r}14- \\
2+ \\
16- \\
14-\end{array}$ & $\begin{array}{l}16- \\
16- \\
16- \\
16-\end{array}$ & $\begin{array}{l}0.3 \\
0.3 \\
0.4 \\
0.5\end{array}$ & $\begin{array}{l}0.3 \\
0.3 \\
0.4 \\
0.6\end{array}$ & $\begin{array}{l}\text { Has been taking vitamin B } \\
\text { (Liq. oryzanin } 20 \text { c.c.) } \\
\text { since 4. III } \\
\text { Yakriton }(1 / 2 \text { Unit) inject- } \\
\text { ed every other day } \\
\text { Increase of glyoxalase } \\
\text { evident }\end{array}$ \\
\hline $\begin{array}{c}8 \\
\text { T. } 0 . \\
22\end{array}$ & $\begin{array}{c}\text { Bron- } \\
\text { chitis }\end{array}$ & $\begin{array}{r}\text { 2. IV } \\
9 . \quad " \\
\text { 12. }\end{array}$ & $\begin{array}{c}16- \\
13- \\
3-\end{array}$ & $\begin{array}{c}16- \\
15- \\
4-\end{array}$ & $\begin{array}{l}0.2 \\
0.2 \\
0.3\end{array}$ & & $\begin{array}{l}\text { Has been taking vitamin } B \\
\text { for many days } \\
\text { Yakriton ( } 1 / 2 \text { Unit) inject- } \\
\text { ed every other day } \\
\text { Inclination of increase of } \\
\text { glyoxalase }\end{array}$ \\
\hline
\end{tabular}


Table 3.

Increase of glyoxalase in Group III.

Group of cases treated with yakriton.

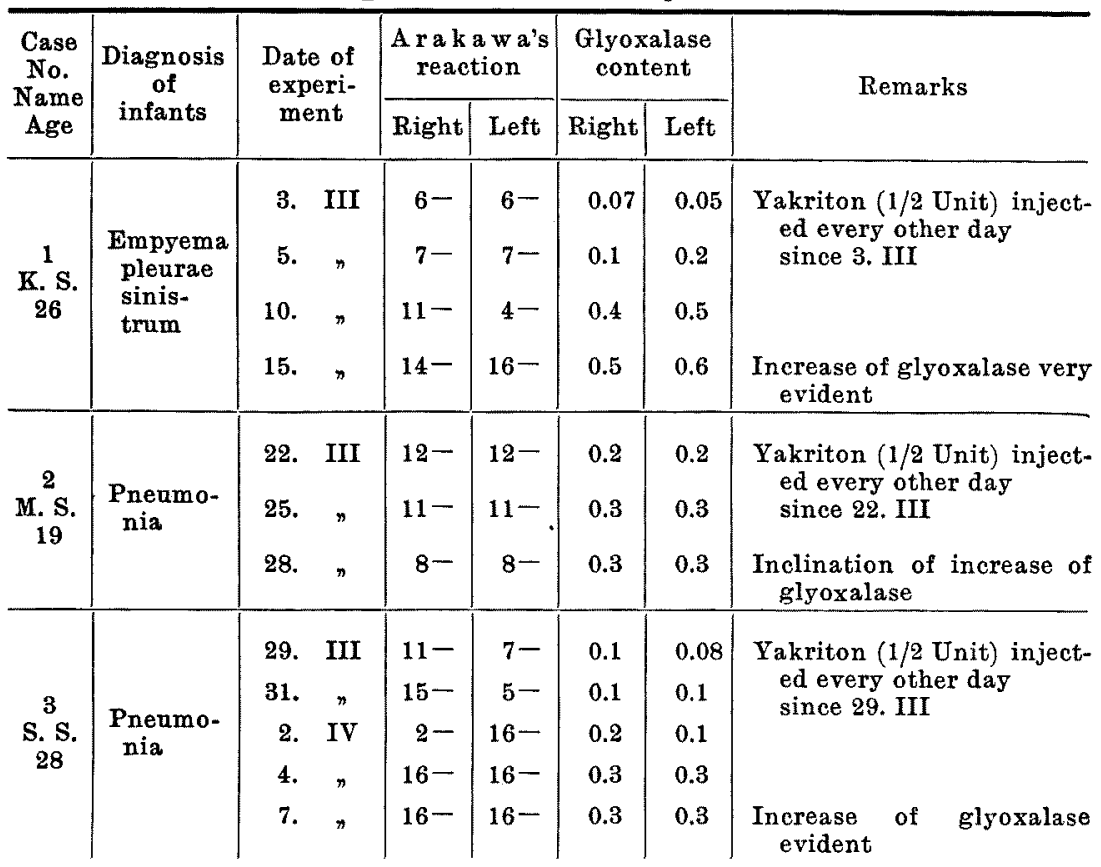

TABLE 4.

Inerease of glyoxalase in Group IV.

Group of cases with no treatment.

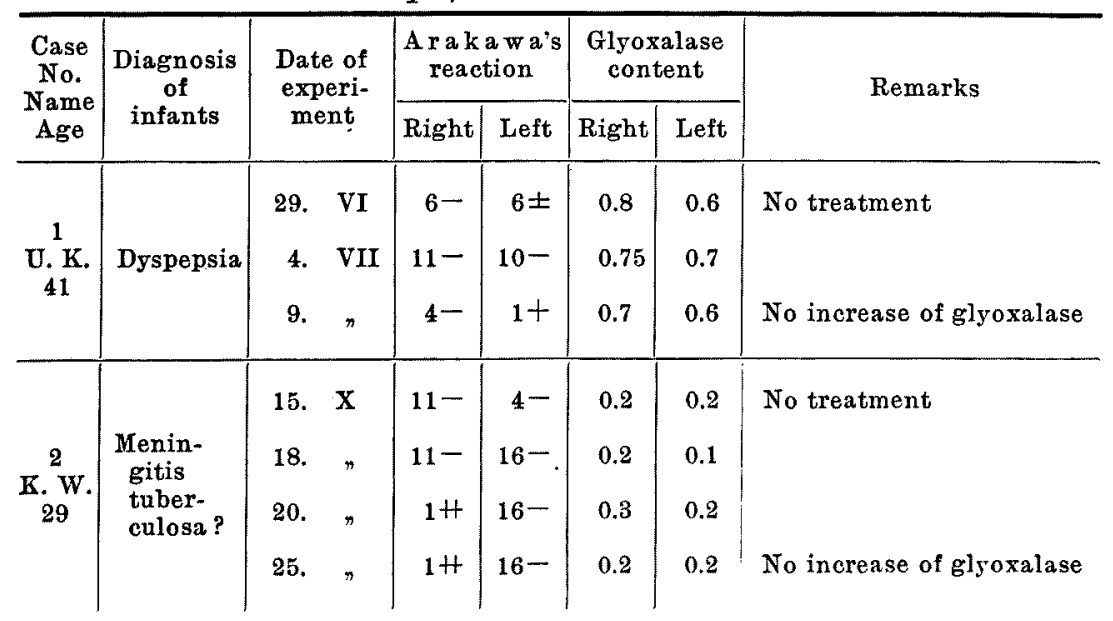




\section{Comment.}

As has been related above, the present investigation was a clinical experiment and at the same time a therapeutically important procedure, so that the number of cases of each group was very different. The cases belonging to Group III-or those treated with yakriton alonewere few in number, because I did not want to treat B-avitaminotic cases with yakriton alone without a simultaneous administration of vitamin $\mathrm{B}$ (Cf. the paper of $\mathrm{K} \mathrm{i} \mathrm{m} \mathrm{ura} \mathrm{a}^{15}$ ). Much less did I want to have Arakawa-negative mothers untreated. This is the reason why there were only 2 cases in Group IV. Findla $y^{6)}$ reported in his paper that the glyoxalase content of the liver in pigeons with beriberi is less than that in control pigeons, and that an administration of vitamin $B$ to a beriberic pigeon is followed by an increase in the glyoxalase content of the liver. My own result will show a similar effect of vitamin B in the line of milk. Only my experiment was a clinical one and these mothers were very probably in a chronic B-avitaminotic state. If my cases had all been really healthy and made acutely $B$-avitaminotic on purpose by an avitaminotic feeding, then the result on vitamin administration might have been much more pronounced.

If Arakawa's reaction is considered from the glyoxalase point of view, then the significance is very clear. Human milk positive to A rakawa's reaction is, as a preceding paper of mine has shown, rich in glyoxalase, and Arakawa-negative milk is poor in the enzyme. And if vitamin $B$ is administered to mothers with negative Arakawa's reaction, then glyoxalase will increase towards the content of the enzyme in the Arakawa-positive milk. Yakriton is used to fortify or mobilize vitamin $B$ as has been shown by Kimura's ${ }^{15)}$ paper, even when vitamin $B$ is not used at the same time, as will be seen from the papers of $\mathrm{Ishii^{16) }}$ and Kurosawa $\mathbf{a}^{17)}$ especially.

\section{Conclusion.}

Glyoxalase in human milk of "healthy" mothers negative to A rakawa's reaction will increase on an administration of vitamin $B$.

15) J. Kimura, Tohoku J. Exp. Med., 1936, 28, 55.

16) M. Is h i i, Tohoku J. Exp. Med., 1935, 27, 532.

17) T. Kurosawa, Tohoku J. Exp. Med., 1937, 31, 260. 